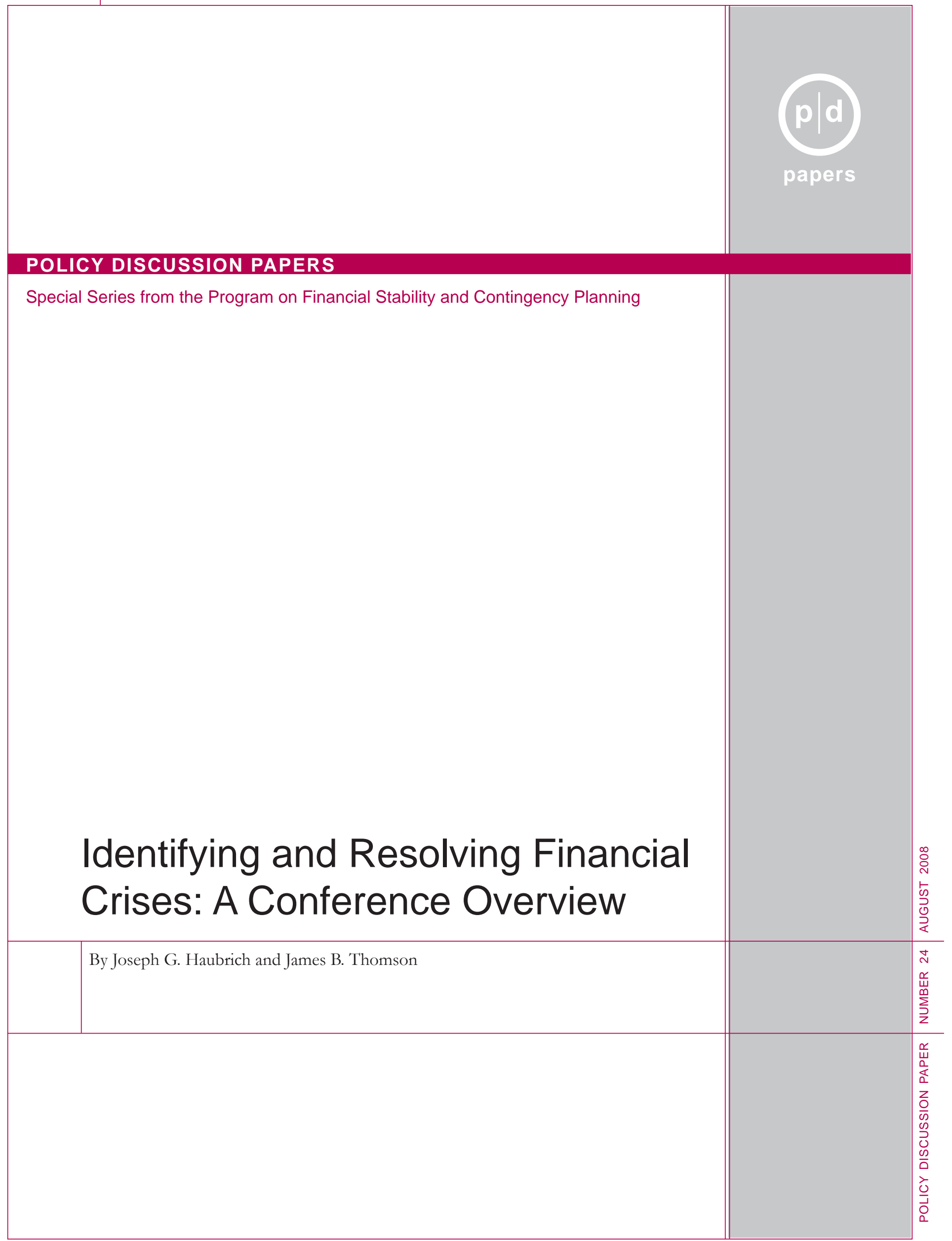




\title{
Identifying and Resolving Financial Crises: A Conference Overview
}

\author{
By Joseph G. Haubrich and James B. Thomson
}

\begin{abstract}
Financial crises remain a recurring problem despite, or perhaps, as some suggest, because of, extensive innovation in capital markets over the past several decades. Crisis interventions are fraught with trade-offs: What are the costs of doing nothing? What is the probability that markets will seize up? Are there viable alternatives? Will the intervention make further crises more likely? The Federal Reserve Bank of Cleveland and the FDIC sponsored a conference in April 2008 to debate and exchange ideas on these issues. The following document summarizes and ties together the contributions presented.

Conference papers can be found at http://www.clevelandfed.org/research/conferences/2008/4_17-18/index.cfm.
\end{abstract}

Joseph G. Haubrich is a consultant and economist at the Federal Reserve Bank of Cleveland and James B. Thomson is a vice president of policy analysis at the Bank.

Materials may be reprinted, provided that the source is credited. Please send copies of reprinted materials to the editor.

Policy Discussion Papers are published by the Research Department of the Federal Reserve Bank of Cleveland. To receive copies or to be placed on the mailing list, e-mail your request to 4dsubscriptions@clev.frb.org or fax it to 216-579-3050. Please send your questions comments, and suggestions to us at editor@clev.frb.org.

Policy Discussion Papers are available on the Cleveland Fed's site on the World Wide Web: www.clevelandfed.org/Research.

Views stated in Policy Discussion Papers are those of the authors and not necessarily those of the Federal Reserve Bank of Cleveland or of the Board of Governors of the Federal Reserve System. 


\section{Introduction}

When this conference was first planned in early 2007, our call for papers included the line, "Accordingly, the time for discussions regarding the response to financial instability is during times of relative calm to ensure the comprehensive consideration of all factors that may influence response." Of course, by the day of the conference, in April 2008, the notion that we were in a period of relative calm was laughable. Still, that gave the conference extra relevance, as the importance of controlling ideas and policies became apparent.

The conference consisted of seven papers, each discussed, and a panel of three practitioners from the regulatory and central banking side.

The first set of papers looked at the theory underlying the approach to financial crises. In "Payoff Complementarities and Financial Fragility: Evidence from Mutual Fund Outflows," Qi Chen, Itay Goldstein, and Wei Jiang explored the issue of strategic complementarities, often thought to generate financial fragility. Finding empirical evidence, however, has been a challenge. They derived empirical implications from a global-game model and tested them using data on mutual fund outflows. Consistent with the theory, they found that conditional on low past performance, funds with illiquid assets (where complementarities are stronger) are subject to more outflows than funds with liquid assets. Moreover, this pattern disappears in funds that are held primarily by large, institutional investors (who can internalize the externalities). They showed that alternative explanations based on information conveyed by past performance or on clientele effects seemed inconsistent with the evidence.

The discussant, Chester Spatt, argued that the complementarities from strategic outflows were perhaps not quantitatively important for mutual funds, but did matter for hedge funds. He suggested that other forms of complementarity, such as market timing, might be more important for mutual funds.

In "Regulating International Capital Flows: An Externality View," Anton Korinek explored how international capital flows impose a macroeconomic externality on economies, which can make them more prone to financial instability and crises. Every capital inflow entails future outflows in the form of repayments, dividends, or profit distributions. However, the private recipients of capital inflows do not internalize the idea that such outflows lead to a general macroeconomic tightening of liquidity in states of nature when international borrowing constraints are binding (such as during financial crises). Specifically, capital outflows force a reduction in aggregate demand and put pressure on exchange rates, which in turn reduces the country's creditworthiness further, tightening borrowing constraints and leading to a vicious cycle of falling exchange rates, tightening borrowing constraints, and falling aggregate demand.Therefore, private recipients of capital flows impose an externality on the rest of the economy:A social planner would

Payoff Complementarities and Financial Fragility: Evidence from Mutual Fund Outflows

Qi Chen, Itay Goldstein, and Wei Jiang

Regulating International Capital Flows: An Externality View

Anton Korinek 
value payoffs in constrained states more highly than decentralized agents do. Korinek constructs a "social pricing kernel," which prices emerging market liabilities at their true social cost and shows that the externality created by a particular asset depends on the covariance of its payoffs with the extent of borrowing constraints (that is, with financial crises). For example, uncontingent foreign-currency-denominated assets, which mandate high payoffs in crisis states, are associated with large externalities; by contrast, flows of foreign direct investment, which typically yield no profit flow during crises, are free of externalities.

The discussant, Eric Fischer, wondered about the treatment of expectations in the model, and proposed reinterpreting the results as reflecting a cash-in-advance constraint. He also suggested that the experiences of Thailand and Korea in the east Asian crisis of 1997 provide evidence for the externality approach of the paper.

The next set of papers looked at external effects in financial markets. The paper, "Imperfect Competition in the Interbank Market for Liquidity as a Rationale for Central Banking," by Viral V. Acharya, Denis Gromb, and Tanju Yorulmazer, studied liquidity transfers between banks through the interbank borrowing and asset sale markets when (i) surplus banks providing liquidity have market power, (ii) there are frictions in the lending market due to moral hazard, and (iii) assets are bank-specific.The authors showed that when the outside options of needy banks are weak, surplus banks may strategically under-provide lending, thereby inducing inefficient sales of bank-specific assets. A central bank can ameliorate this inefficiency by standing ready to lend to needy banks, provided it has greater information about banks (for example, through supervision) compared to outside markets, or is prepared to extend loss-making loans. The public provision of liquidity to banks, in fact the mere credibility of public liquidity support, can improve the private allocation of liquidity among banks. This rationale for central banking finds support in historical episodes preceding the modern era of central banking and has implications for recent debates on the supervisory and lender-of-last-resort roles of central banks.

The discussant, Stacey Schreft, related the central tenets of the paper to current events, in particular, the recent problems at Bear Stearns and the circumstances surrounding its acquisition by JP Morgan Chase.The one result of the Acharya et al. paper that doesn't fit the events of the Bear Stearns' episode is the credibility result.That is, in the presence of a credible commitment for public liquidity support, private markets will make liquidity available to solvent financial firms, which did not occur in the case of Bear Stearns.

In the next paper, “The Risks of Bank Wholesale Funding," Rocco Huang and Lev Ratnovski note that some commercial banks increasingly use short-term wholesale funding in addition to traditional retail deposits. How does this affect their credit and liquidity risks? They analyzed a depository bank's decision to attract wholesale funds, and the

The Risks of Bank Wholesale Funding

Rocco Huang and Lev Ratnovski 
wholesale financier's decision to become informed. In the presence of relatively passive depositors, wholesale financiers can remain uninformed and withdraw upon mild negative news, triggering inefficient liquidations. Banks do not internalize such liquidity risk, particularly when a joint failure and a central bank intervention are likely in bad states. The model sheds light on the recent credit crisis, explaining why wholesale financiers did not provide market discipline ex ante and exacerbated liquidity risks ex post.

The discussant, Antoine Martin, pointed out that in contrast to the paper, some empirical evidence suggests banks get into trouble when they have too many wholesale depositors. What aspects of the economic environment lead to too many or too few wholesale depositors?

In "Which Banks Recover from a Banking Crisis?" Emilia Bonaccorsi di Patti and Anil K. Kashyap analyzed the fate of 120 Italian banks that experienced abrupt drops in profitability.About one-third of these banks subsequently attained comparable levels of profitability. In the years prior to the performance decline, it appears that the banks that got into trouble were lending to riskier clients than the average in the overall economy. One important factor governing recovery is the size of the initial profit drop that occurs at the onset of distress. The general business climate after the shock also matters. But so does the adjustments made by the bank in the wake of the shock.Thus, recovery depends both on factors that banks can and cannot control.Among the factors that the bank can influence, the ability to adjust the loan portfolio is critical: Recovering banks show consistently lower default rates on loans in the post-shock period. Some of this appears to occur because recovering banks that have a large share of high-risk customers are aggressively trimming loans.

The discussant, Emre Ergungor, asked,"Are bankers who know they will recover treating their customers differently or is the way they treat their customers causing the recovery?" He also thought the paper could do more to control for bank characteristics.

The next paper,"How Does Competition Affect Efficiency and Soundness in Banking? New Perspectives and Empirical Evidence," by Klaus Schaeck and Martin Cihák, questioned a growing body of literature that indicates competition increases bank soundness.They used an industrial-organization-based approach to offer new perspectives and empirical evidence, and their results suggest that efficiency plays a key role in the transmission mechanism from competition to soundness. Using a two-pronged approach, they first established the link between competition and measures of profit efficiency in banking. Second, they employed the Boone indicator, an innovative measure of competition that focuses on the impact of competition on the performance of efficient banks, and relate this measure to bank soundness. Findings from Granger causality tests from two complementary samples of European and U.S. banks for 1995-2005 indicated that competition increases bank efficiency. Building on these results, the paper examined
Which Banks Recover from a Banking Crisis?

Emilia Bonaccorsi di Patti and Anil K. Kashyap

How Does Competition Affect Efficiency and Soundness in Banking? New Perspectives and Empirical Evidence

Klaus Schaeck and Martin Cihák 
the relation between the Boone indicator and bank soundness, and found evidence that competition robustly increases bank soundness, via the efficiency channel.

Ken Jones, the discussant, argued that "The findings actually highlighted the difficulties in finding predictors that could presage banking crises across a wide cross-section of countries with an acceptable proportion of 'missed crises' and 'false alarms.'” He suggested controlling for the onset of currency crises and adding more macroeconomic factors into the equations.

In "The Impact of Revenue Diversity on Banking System Stability," Olivier De Jonghe used extreme value analysis to look at the dismantling of legal barriers to the integration of financial services, one of the major recent developments in the banking industry.This development led to an expansion of the variety of financial intermediaries and types of transactions. However, this trend may have altered banks' risk-taking incentives and affected overall banking-sector stability. This paper analyzes how banks' divergent strategies toward specialization and the diversification of financial activities affect their ability to shelter themselves from adverse economic conditions. To this end, market-based measures of banks' extreme systematic risk were generated, using techniques developed for extreme value analysis. Extreme systematic risk captures the probability of a sharp decline in a bank's stock price, conditional on a crash in a market index. Subsequently, the impact of (the correlation between) interest and non-interest income (and its components) on this risk measure is assessed.The estimation results reveal that the heterogeneity in extreme bank risk can partially be attributed to differences in banks' reliance on nontraditional banking activities.All non-interest-generating activities increase banks' sensitivity to the market index during times of extreme equity market movements. In addition, smaller banks and well-capitalized banks are better able to withstand large adverse economic conditions. Furthermore, the effects are stronger during times of market turbulence than under normal economic conditions.

The discussant, Rich Rosen, applauded the author for bringing extreme value analysis to bear on the problem, but then suggested that nonlinear techniques beyond correlation would give a better view of the relations between variables.

\section{Regulators' Panel Discussion}

The Regulators' Panel Discussion brought together three thoughtful regulators and policymakers to reflect on past, current, and future crises:

Sarah Carlson, of Great Britain's Financial Services Authority, spoke on some tools that the FSA has to help predict when firms might get into trouble. The FSA has a product sales database for mortgages, which contains details of all regulated mortgages in the U.K. since 2005, including repossession data. This dataset can be quite powerful in identifying outliers in the population of FSA-regulated lenders and mortgage brokers. Of 
particular interest is the fact that the U.K. postcode is much more granular than the U.S. zip code, usually containing only about 20 households.

In addition, the FSA runs "War Games"- exercises designed to bring authorities together and practice for an actual financial crisis. In part, the exercises are designed to "avoid fighting the last war." The practice, and the tool kit, though useful, were found wanting in the Northern Rock situation-it seems additional tools are necessary and additional support is needed for a nonzero failure policy. New legislation will be forthcoming in this session of Parliament that will augment the regulatory toolkit available to the U.K. authorities.

Patricia Mosser, of the Federal Reserve Bank of New York, talked from her point of view at the Open Market Desk about the past eight months and, more specifically, the six weeks prior to the conference.

She saw the past eight months as a classic deleveraging cycle, but larger and longer than others in recent memory. The "shock" (falling home prices) led to financialinstitution losses and writedowns, some of which were very large, because the outsized decline in house prices combined with financing instruments that were highly leveraged, opaque, and complex. As leveraged investors took losses, they faced margin calls, causing them to sell assets, which pushed asset prices lower, leading to additional margin calls, and further selling. This cycle accelerated (in August-September, late NovemberDecember, and March) and decelerated (October and January-February) in highly nonlinear and unpredictable ways.As deleveraging accelerated, asset price volatility jumped and market liquidity declined market by market, from least liquid to most liquid.As market liquidity fell, the originate-to-distribute credit mechanisms stopped, and banks and dealers reintermediated large quantities of assets (both low and high quality) back onto their balance sheets. Similarly, high volatility and uncertainty caused significant decline in market-making activities.

For financial institutions, the most obvious manifestation of the market turmoil was the high cost of unsecured term funding, exemplified by term LIBOR rates. Constraints on balance sheets, combined with concerns about where losses were located, caused both higher demand for term funding and a reduction in supply. In early March, market liquidity and functioning deteriorated sharply until even Treasury markets and repos (borrowing collateralized by securities) were significantly impaired.This impairmentparticularly the near-overnight unwillingness of market participants to lend to Bear Stearns even on a secured basis-was the proximate cause of the firm's demise. But the possibility of a widespread run across all repo-market borrowers (a $\$ 4$ trillion-daily market) was the systemic event that prompted the creation of the Primary Dealer Credit Facility.

Mosser saw several take-away lessons from the situation so far. Financial regulation and the lender of last resort need rethinking, particularly in light of Bear Stearns and 
the Primary Dealer Credit Facility. Thinking about which institutions are covered by the lender-of-last-resort service and what counts as "systemic" importance seems vital. Being a supervisor is essential to being a lender of last resort, because the lender needs a better view into the firms it lends to, thus implying some extension of supervision to nonbanks. Stigma matters, so a standing facility that works fine in normal times may not work so well in times of crises. Finally, international coordination matters, particularly when large global institutions are involved and spillovers are across borders.

John Bovenzi of the FDIC concluded the panel. He spoke about the resolution process for troubled banks. Bovenzi argued that the legal framework and operational procedures both matter. In the 1980s and 1990s, many small banks failed, and the FDIC protected all depositors, and thus prevented bank runs, but as a result did not impose any depositor discipline. In the larger case of Continental Illinois, the FDIC provided assistance to an open bank, at a cost of about $\$ 1$ billion. All deposits were protected, but even if a decision had been made to leave uninsured depositors with some losses, there were difficult operational issues involved in separating insured from uninsured deposits in a timely manner at such a large bank.

FDICIA changed the process, adding prompt corrective action and a least-cost test with a systemic risk exemption. Small banks are usually closed on a Friday, opened again on Monday as part of another bank that has purchased the closed bank.This can happen because the FDIC generally has begun work on the problem 90 days in advance. Separating uninsured from insured deposits is still complicated, but uninsured depositors do bear losses.

Big banks are more complex-as one example, when do you close a bank that has branches in time zones around the world, so that in some sense the bank never closes? Creating a bridge bank that continues the operation but can force losses on creditors is a solution. The FDIC is working on a proposal that the largest banks must be able to put a hold on a portion of large accounts if requested by the FDIC in order to facilitate the resolution process at larger banks.

John then raised the question about the possibility of closing investment banks, such as Bear Stearns, as if they were a bank. With a bridge structure, the firm could have kept running, but the shareholders likely would have taken a complete loss.

Following the panel discussion, a lively discussion involving the other conference attendees ensued, ranging across issues such as GAAP versus economic capital, problems of moral hazard, and the economic costs of financial collapse.

\section{Conclusion}

Recent events in financial markets illustrate the importance of work, both academic and applied, on identifying and resolving financial crises. Overall, the papers, discussants' re- 
marks, panelists' comments, and the discussion by the attendees centered on three major themes. First is the role of liquidity in financial stability. Liquidity shocks, whether they are the result of firm-level decisions, reversals of international capital flows, or flights to quality, are prime factors in propagating financial crises. The credible public provision of liquidity, a role typically played by central banks, is thus an important element in promoting financial stability. Second, financial stability can be enhanced by policies that minimize externalities which drive a wedge between private decisions and public welfare. Public financial safety nets or time-inconsistent failure-resolution policies produce moral hazard incentives, which are inconsistent with financial stability. Finally, identifying financial crises ex ante is an area that merits increased research focus.

\section{Conference Papers}

Imperfect Competition in the Interbank Market for Liquidity as a Rationale for Central Banking Viral V. Acharya, Denis Gromb, and Tanju Yorulmazer

April 2008

Payoff Complentarities and Financial Fragility: Evidence from Mutual Fund Outflows

Qi Chen, Itay Goldstein, and Wei Jiang

May 2007

The Impact of Revenue Diversity on Banking System Stability

Olivier De Jonghe

(undated)

Which Banks Recover from a Banking Crisis?

Emilia Bonaccorsi di Patti and Anil K. Kashyap

April 4, 2008

The Risks of Bank Wholesale Funding

Rocco Huang and Lev Ratnovski

March 2008

Regulating International Capital Flows: An Externality View

Anton Korinek

University of Maryland working paper, December 13, 2007

How Does Competition Affect Efficiency and Soundness in Banking? New Perspectives and Empirical Evidence

Klaus Schaeck and Martin Cihák

April 2008 


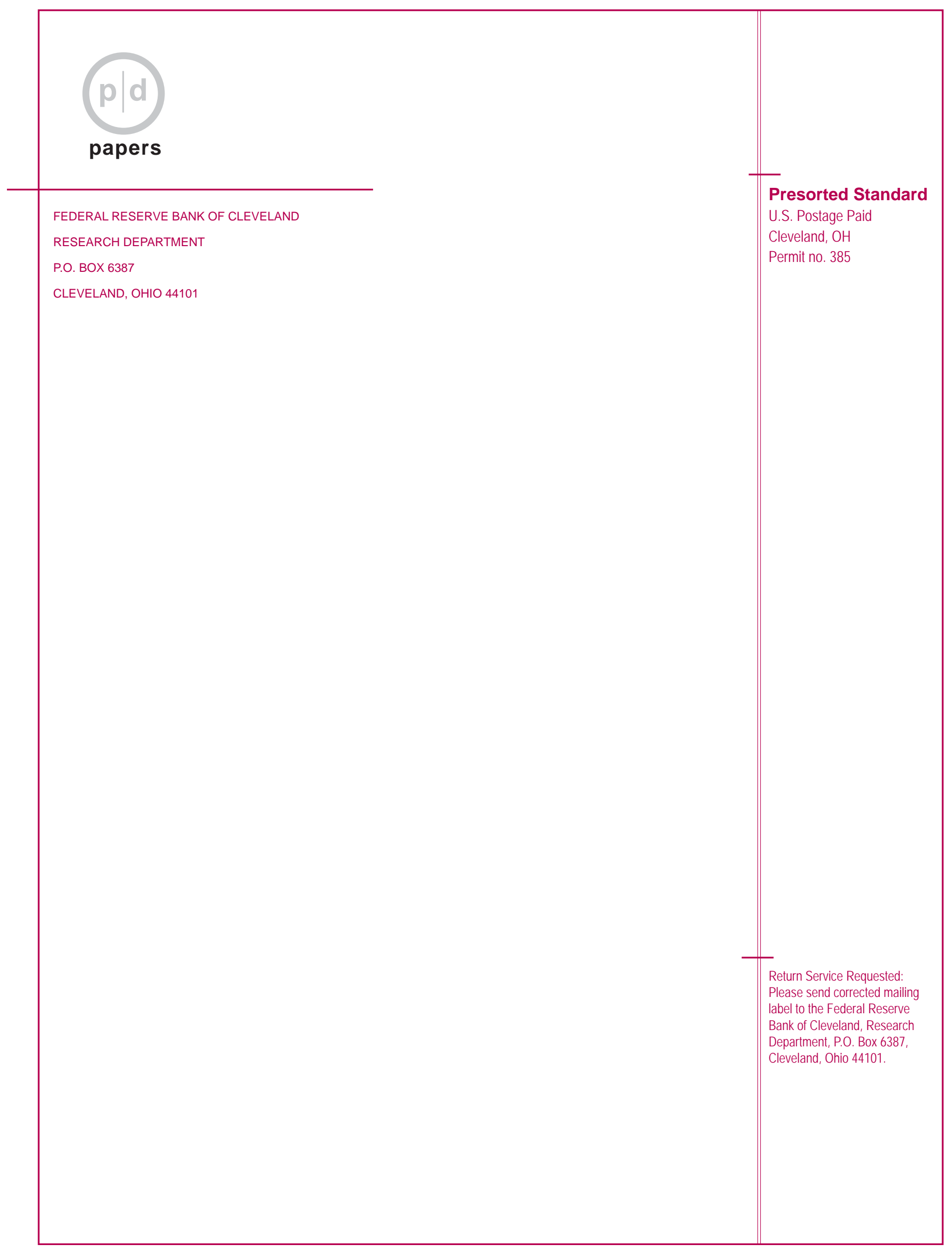

